\title{
Occupational exposure to poultry and prevalence of antibodies against Marek's disease virus and avian leukosis retroviruses
}

\author{
D Choudat, G Dambrine, B Delemotte, F Coudert
}

\begin{abstract}
Objectives-To compare the prevalence of antibodies against Marek's disease herpes virus (MDV) and against avian leukosis viruses type $C$ (ALV) in groups of workers exposed to poultry and in unex-
\end{abstract} posed groups.

Methods-Antibodies directed against avian viral proteins were detected by enzyme linked immunosorbent assay in 549 subjects. Exposure to chickens was high in two subgroups: farmers on intensive chicken farms and workers at chicken slaughterhouses. One subgroup, traditional farmers on dairy or pig farms with poultry, had moderate exposure to poultry. Another subgroup, farmers and slaughterhouse workers on quail farms, had high exposure to quails. Three subgroups were not exposed to chickens: farmers on dairy or pig farms without poultry, workers at cattle slaughterhouses, and white collar workers. Also, MDV antibodies were tested after serum sample adsorption with chicken antigens in 134 serum samples.

Results-The prevalence of antibodies against MDV was significantly higher in the exposed subgroups than in unexposed groups (odds ratio (OR) $6 \cdot 17$; 95\% confidence interval $(95 \%$ CI $3 \cdot 91-9 \cdot 75)$. No association was found between seroprevalence and age. However, higher prevalence was found among women and was related to duration of exposure to chickens. The concentration of antibodies from a few subjects remained very high after adsorption. Significant differences between the men and women were found for the prevalence of antibodies for ALV but were not related to exposure to chickens.

Conclusions-The prevalence of antibodies against MDV was significantly higher among workers exposed to chickens and was related to sex and duration of exposure. The higher prevalence of antibodies against avian oncogenic viruses found among women compared with men may be induced by differences in exposure or by genetic factors. The meaning of these high titres could be related to the presence of MDV in humans. Because the involvement of animal oncogenic viruses in human cancer is indicated by epidemiological and some experimental studies, the integration of viral DNA in human cells needs to be investigated.

(Occup Environ Med 1996;53:403-410)

Keywords: avian oncogenic viruses; antibodies; occupational exposure

Most studies have found increased risks of leukaemia, Hodgkin's disease, non-Hodgkin's lymphoma, and multiple myeloma among farmers, breeders, and veterinarians. ${ }^{1-19}$ Higher prevalences of cancers of the haematopoietic and lymphatic systems have also been found among slaughterhouse workers and meat workers. ${ }^{20-24}$ These cancer risks vary according to the types of cancer, sex, and country. ${ }^{1-524}$ The origin of the increased risk has not yet been identified and may be related either to non-specific stimulation of the immune and haematological systems, or to exposure to environmental carcinogens such as pesticides or viruses, especially bovine leukaemia virus, Marek's disease herpes virus (MDV), and avian leukosis retroviruses (ALV). ${ }^{325}$ However, epidemiological arguments for the involvement of avian oncogenic viruses are inconsistent. Milham found an excess risk of leukaemia among poultry farmers. ${ }^{10}$ Priester and Mason also detected an excess risk of multiple myeloma in people living in counties with areas of higher poultry populations. ${ }^{11}$ In contrast, they did not find a significant excess of lymphomas, Hodgkin's disease, or leukaemia in these areas. ${ }^{11}$ Eriksson and Karlsson found increased risks of multiple myeloma associated with exposure to cattle, horses, and goats but not with poultry. ${ }^{12}$ However, they did not study sex or occupational factors in the risks of cancer. ${ }^{5}$

Also, MDV and ALV are very common in poultry and can induce neoplastic proliferation of lymphoid cells. ${ }^{26}{ }^{27}$ The ALV is vertically transmitted in chickens and is also transmitted by blood contact. The MDV is horizontally transmitted by contaminated airborne particles. The viral particles are present at a very high density in the air of the breeding farms and chicken slaughterhouses. These particles are inhaled by workers and might be at the origin of infection in susceptible humans. However, there is little evidence of transmission to humans. Certain strains of sarcoma virus related to ALV also induce tumours in mammals and transform human cells in culture. ${ }^{28}$ 
Nastac et al found antibodies against ALV in fowl farm workers and in leukaemic and healthy subjects by complement fixation reaction. ${ }^{29} 30$ Antibodies against MDV were also found among a few farmers working on poultry farms. ${ }^{3132}$ Sharma et al detected antibodies against MDV by immunofluorescence in $6 \%$ of human serum samples, but without apparent correlation between the extent of viral contact and the occurrence of antibodies. ${ }^{33}$ However, antibodies against avian oncogenic viruses were not found consistently in the various studies or they were reported as non-specific reactions. ${ }^{34-40}$ We therefore conducted a preliminary study among 20 control subjects and 98 workers exposed to poultry. We found positive serum samples in some exposed workers.

We decided to verify the presence of antibodies against MDV and ALV, to assess their specificity, and to compare the prevalence of these antibodies in different groups of workers exposed and not exposed to poultry.

\section{Population and methods}

\section{POPULATION}

All workers participating in this study were recruited on a voluntary basis. They were selected in six districts in the west and north east of France. Questionnaires and blood samples were obtained from November 1990 to May 1991 by the occupational health services. The population studied included three main types of activity: farmers, slaughterhouse workers, and white collar workers.

A total of 582 subjects were divided into seven subgroups according to the type of exposure to animals (table 1 ).

The group highly exposed to chickens included two subgroups with high exposure to chickens: farmers on intensive chicken farms and workers at chicken slaughterhouses.

One group was highly exposed to quails: farmers and slaughterhouse workers on quail farms.

One group had moderate exposure to poultry: traditional farmers on dairy or pig farms with poultry.

The group which was not exposed to chickens included three subgroups: farmers on dairy or pig farms without poultry, workers at cattle slaughterhouses, and white collar workers not exposed to cattle and poultry (clerical workers).

The subjects of the preliminary study were not included.

\section{QUESTIONNAIRE}

Each subject completed their own questionnaire about personal characteristics, type of work (farmer, slaughterer, white collar worker), and type and duration of exposure to animals (chickens, turkeys, ducks, quails, cattle, pigs ...). For each subject, the same number was used to identify the questionnaire and the blood sample.

\section{BLOOD COLLECTIONS}

Blood from the subjects was collected by venepuncture into two dry $10 \mathrm{ml}$ tubes. The blood was centrifuged and the serum samples were separated into two $5 \mathrm{ml}$ tubes. These tubes were numbered, stored at $-20^{\circ} \mathrm{C}$, and posted on carbonic ice to the laboratory, which was blind to the type of exposure of the serum samples being screened.

One batch of 20 samples thawed during posting and the volume of some samples was not sufficient for serological tests. The final analysis was therefore of 549 samples.

\section{SEROLOGICAL TESTS}

Preparation of avian retroviral proteins

A specific strain of ALV (avian myeloblastosis virus, subgroup B) was purified from plasma of leukaemic chickens by two sequential equilibration centrifugations on sucrose gradients of $20 \%-60 \%$ (wt/vol). ${ }^{41}$ The virus pellet was dissolved in buffer, $\mathrm{pH} 8 \cdot 1$, containing $10 \mathrm{mM}$ Tris-base, $1 \mathrm{mM}$ EDTA, and $100 \mathrm{mM} \mathrm{NaCl}$ (TEN). The protein concentration was measured with a BCA protein assay reagent (Pierce Chemical Company, Rockford, Illinois, USA ${ }^{42}$ based on a modification of the Lowry method. ${ }^{43}$ Aliquots of the protein preparation were stored at $-80^{\circ} \mathrm{C}$ before use.

\section{Marek's disease virus purification}

The HPRS ${ }_{16}$ strain of MDV was used..$^{44}$ The HPRS $_{16}$ strain was purified from feather folli-

Table 1 Demographic characteristics of the group not exposed to chickens and three subgroups: moderate exposure to chickens; high exposure to chickens (including two subgroups), and exposed to quails

\begin{tabular}{|c|c|c|c|c|c|c|c|c|c|}
\hline \multirow[b]{2}{*}{ Groups and subgroups } & \multicolumn{3}{|c|}{ Number } & \multicolumn{3}{|l|}{ Age (y) } & \multicolumn{3}{|c|}{ Duration of exposure to animals $(y)$} \\
\hline & Men & Women & Total & $\begin{array}{l}\text { Men } \\
\text { mean }(S D)\end{array}$ & $\begin{array}{l}\text { Women } \\
\text { mean }(S D)\end{array}$ & $\begin{array}{l}\text { Total } \\
\text { mean (SD) }\end{array}$ & $\begin{array}{l}\text { Men } \\
\text { mean }(S D)\end{array}$ & $\begin{array}{l}\text { Women } \\
\text { mean }(S D)\end{array}$ & $\begin{array}{l}\text { Total } \\
\text { mean }(S D)\end{array}$ \\
\hline \multicolumn{10}{|l|}{ Group unexposed to chickens: } \\
\hline White collar workers & 89 & 63 & 152 & $38(10)$ & $37(11)$ & $38(11)$ & 0 & 0 & 0 \\
\hline $\begin{array}{l}\text { Workers at cattle slaughterhouses } \\
\text { Farmers on dairy or pig farms }\end{array}$ & 63 & 21 & 84 & $33(10)$ & $33(9)$ & $33(10)$ & $12(12)$ & $6^{\star}(4)$ & $10(11)$ \\
\hline $\begin{array}{l}\text { without poultry } \\
\text { Group with moderate exposure to } \\
\text { chickens: }\end{array}$ & 42 & 14 & 56 & $41(13)$ & $43(11)$ & $42(12)$ & $21(13)$ & $24(12)$ & $22(13)$ \\
\hline $\begin{array}{l}\text { Farmers on dairy or pig farms } \\
\text { with poultry } \\
\text { Group highly exposed to chickens: }\end{array}$ & 33 & 12 & 45 & $47(13)$ & $46(13)$ & $46(13)$ & $31(18)$ & $20(17)$ & $26(18)$ \\
\hline $\begin{array}{l}\text { Farmers on intensive chicken farms } \\
\text { Workers at chicken slaughterhouses }\end{array}$ & $\begin{array}{l}54 \\
33\end{array}$ & $\begin{array}{l}43 \\
17\end{array}$ & $\begin{array}{l}97 \\
50\end{array}$ & $\begin{array}{l}33(9) \\
40(10)\end{array}$ & $\begin{array}{l}32(9) \\
41(11)\end{array}$ & $\begin{array}{l}32(9) \\
40(10)\end{array}$ & $\begin{array}{r}8(6) \\
12(9)\end{array}$ & $\begin{array}{l}6(6) \\
9(4)\end{array}$ & $\begin{aligned} 7(6) \\
11(8)\end{aligned}$ \\
\hline $\begin{array}{l}\text { Group exposed to quails: } \\
\text { Workers on quail farms including } \\
\text { quail slaughter }\end{array}$ & 25 & 40 & 65 & $33(7)$ & $37^{\star}(12)$ & $35(11)$ & $7(6)$ & $9(5)$ & $9(5)$ \\
\hline
\end{tabular}

$\star \mathrm{P}<0.04$ men $v$ women 
Table 2 Prevalence of titres of antibodies against Marek's disease virus by group (men)

\begin{tabular}{|c|c|c|c|c|c|c|c|c|c|c|}
\hline \multirow[b]{2}{*}{ Groups } & \multicolumn{10}{|c|}{ Titres of antibodies against Marek's disease virus } \\
\hline & $1 / 80$ & $1 / 160$ & $1 / 320$ & $1 / 640$ & $1 / 1280$ & $1 / 2560$ & $1 / 5120$ & $1 / 10240$ & $1 / 20480$ & $1 / 40960$ \\
\hline \multicolumn{11}{|l|}{ Group unexposed to chickens: } \\
\hline $\begin{array}{l}\text { White collar workers }(\mathrm{n}=89) \% \\
\text { Workers at cattle slaughterhouses }\end{array}$ & $23 \cdot 6$ & $29 \cdot 2$ & $29 \cdot 2$ & $13 \cdot 4$ & $2 \cdot 3$ & $2 \cdot 3$ & - & - & - & - \\
\hline$(n=63) \%$ & $17 \cdot 5$ & $\mathbf{4 4} \cdot 4$ & $33 \cdot 3$ & $3 \cdot 2$ & $1 \cdot 6$ & - & - & - & - & - \\
\hline $\begin{array}{l}\text { Farmers on dairy or pig farms } \\
\text { without poultry }(\mathrm{n}=42) \% \\
\text { Group with moderate exposure to chickens: }\end{array}$ & $26 \cdot 2$ & $30 \cdot 9$ & $30 \cdot 9$ & $4 \cdot 8$ & $2 \cdot 4$ & $2 \cdot 4$ & $2 \cdot 4$ & - & - & - \\
\hline $\begin{array}{l}\text { Farmers on dairy or pig farms } \\
\text { with poultry }(\mathrm{n}=33) \% \\
\text { Group highly exposed to chickens: }\end{array}$ & $6 \cdot 1$ & $33 \cdot 3$ & $24 \cdot 2$ & $27 \cdot 3$ & $6 \cdot 1$ & $3 \cdot 0$ & - & - & - & - \\
\hline $\begin{array}{l}\text { Farmers on intensive chicken farms } \\
(n=54) \% \\
\text { Workers at chicken slaughterhouses }\end{array}$ & 13.0 & $14 \cdot 8$ & $29 \cdot 7$ & 13.0 & $11 \cdot 1$ & $7 \cdot 4$ & $1 \cdot 8$ & $5 \cdot 5$ & 3.7 & - \\
\hline $\begin{array}{l}\quad(n=33) \% \\
\text { Group exposed to quails: }\end{array}$ & $12 \cdot 1$ & $12 \cdot 1$ & $18 \cdot 2$ & $33 \cdot 3$ & $9 \cdot 1$ & $9 \cdot 1$ & 3.0 & 3.0 & - & - \\
\hline $\begin{array}{l}\text { Workers on quail farms including } \\
\text { quail slaughter }(n=25) \%\end{array}$ & $32 \cdot 0$ & $16 \cdot 0$ & $36 \cdot 0$ & $8 \cdot 0$ & $4 \cdot 0$ & - & - & - & - & $4 \cdot 0$ \\
\hline
\end{tabular}

cle epithelium. The method of purification was similar to that reported by Coudert et al..$^{45}$ The virus was extracted in phosphate buffered saline (PBS) from the skin and feather follicle tips. After eliminating the debris by low speed centrifugation (16 $000 \mathrm{rpm}$ for one hour), the virus was further purified by zonal centrifugation on a linear sucrose gradient of $20 \%-50 \%$ (wt/vol) in PBS (pH 7.4) for two hours at $26000 \mathrm{rpm}$ at $4^{\circ} \mathrm{C}$. Fractions of the gradient were scanned at $254 \mathrm{~nm}$. Fractions between $47 \%$ and $49 \%$ sucrose showed the presence of viruses. These fractions were pooled, diluted with PBS and sedimented by centrifugation at $36000 \mathrm{rpm}$ for one hour. The virus pellet was resuspended in $\mathrm{PBS}$ and stored at $-70^{\circ} \mathrm{C}$.

\section{Positive control serum samples}

Antiserum samples were prepared by subcutaneous injection of $5 \mathrm{mg}$ of partially purified feather follicle virus $\left(\mathrm{HPRS}_{16}\right.$ ) with Freund's complete adjuvant in multiple sites on the backs of several rabbits. Rabbits were boosted intravenously three times at weekly intervals with $3 \mathrm{mg}$ of partially purified antigen. The serum samples were collected one week after the last injection, inactivated at $56^{\circ} \mathrm{C}$, and stored at $-70^{\circ} \mathrm{C}$.

Serum sample adsorption with chicken antigens The MDV is a cell associated virus and no purification procedure can totally avoid the presence of chicken proteins. It is therefore necessary to check the specificity of the titre found by adsorbing the serum samples to proteins extracted from chicken organs. The specificity of rabbit and human serum samples was increased by adsorbing them with powdered chicken tissue consisting of liver and red blood cells prepared by passing concentrated cell suspensions through acetone. Chickens used were from a specific pathogen free breeding colony without contact with the viruses and established as virus free. The dried tissue powder was mixed with serum samples at $1: 2 \mathrm{v} / \mathrm{v}$ overnight at $4^{\circ} \mathrm{C}$ after which the serum was removed from the pellet by centrifugation. This adsorption was performed on 134 human serum samples (33 men exposed to poultry, 63 men exposed to cattle, 17 women exposed to poultry, and 21 women exposed to cattle).
Detection of antibodies directed against avian oncogenic viruses by enzyme linked immunosorbent assay

Antibodies directed against avian viral proteins were detected by enzyme linked immunosorbent assay (ELISA). Microwells (NUNC $96 \mathrm{~F})$ were coated with $2 \mu \mathrm{g}$ of purified proteins in deionized water and were dried overnight at $38^{\circ} \mathrm{C}$. The protein concentration for crude MDV was $5000 \mu \mathrm{g} / \mathrm{ml}$ and the effective dilution for the test was $1 / 4000$. The concentration for purified MDV was $200 \mu \mathrm{g} / \mathrm{ml}$ and the effective dilution was $1 / 1000$.

After coating, wells were incubated for one hour with a bovine serum albumin solution ( 2 $\mathrm{mg} / \mathrm{ml}$ in carbonate buffer, $\mathrm{pH} 9 \cdot 6$ ) to block free sites. Serial concentrations of human serum samples diluted in PBS containing $10 \%$ newborn calf serum $(100 \mu \mathrm{l})$ were dispensed into the wells. After one hour at $37^{\circ} \mathrm{C}$ plates were washed and horse radish peroxydase conjugate with 2,2'-azino-bis-3-ethylbenz-thiazoline-6-sulphonic acid (ABTS) substrate was used. Coloration was measured with an automatic photometer (Dynalab) at $405 \mathrm{~nm}$.

The samples at each dilution were tested as duplicates. Moreover, the results for each serum sample were expressed by the values of optical density at each dilution and by one titre: the titre of each serum sample was the first dilution with an optical density lower than $0 \cdot 1$.

\section{Specificity of antibodies}

The specificity of antibodies against MDV was tested for cytomegalovirus, Herpes simplex, and Herpes varicellae in 44 subjects with antibodies against MDV and 44 subjects without antibodies against MDV.

The ELISAs were used to detect immunoglobulin $G$ antibodies against cytomegalovirus, Herpes simplex, and Herpes varicellae (ELISA Enzygnost, Behring).

\section{STATISTICAL ANALYSIS}

Standard descriptive statistics were used to represent responses as a frequency distribution and to calculate group means and variances. $\chi^{2}$ Tests were used with $2 \times 2$ contingency tables to find whether relations shown between the qualitative variables were significant. The prevalences of the titres were studied accord- 
Table 3 Prevalence of titres of antibodies against Marek's disease virus by group (women)

\begin{tabular}{|c|c|c|c|c|c|c|c|c|c|c|c|c|}
\hline \multirow[b]{2}{*}{ Groups } & \multicolumn{12}{|c|}{ Titres of antibodies against Marek's disease virus } \\
\hline & $1 / 80$ & $1 / 160$ & $1 / 320$ & $1 / 640$ & $1 / 1280$ & $1 / 2560$ & $1 / 5120$ & $1 / 10240$ & $1 / 20480$ & $1 / 40960$ & $1 / 81920$ & $>1 / 81920$ \\
\hline \multirow{2}{*}{\multicolumn{13}{|c|}{$\begin{array}{l}\text { Group unexposed to chickens: } \\
\text { White collar workers }(n=63) \%\end{array}$}} \\
\hline & $11 \cdot 1$ & $19 \cdot 1$ & $31 \cdot 7$ & $27 \cdot 0$ & $9 \cdot 5$ & $1 \cdot 6$ & - & - & - & - & - & - \\
\hline $\begin{array}{l}(\mathrm{n}=21) \% \\
\text { Farmers on }\end{array}$ & $28 \cdot 6$ & $42 \cdot 8$ & $14 \cdot 3$ & $9 \cdot 5$ & $4 \cdot 8$ & - & - & - & - & - & - & - \\
\hline $\begin{array}{l}\text { without poultry }(n=14) \% \\
\text { Group with moderate exposure to } \\
\text { chickens: }\end{array}$ & $28 \cdot 6$ & $21 \cdot 4$ & $42 \cdot 9$ & 0 & $7 \cdot 1$ & - & - & - & - & - & - & - \\
\hline $\begin{array}{l}\text { Farmers on dairy or pig farms with } \\
\text { poultry }(\mathrm{n}=12) \% \\
\text { Group highly exposed to chickens: } \\
\text { Farmers on intensive chicken }\end{array}$ & $25 \cdot 0$ & $33 \cdot 3$ & $8 \cdot 3$ & $16 \cdot 7$ & 0 & 0 & $16 \cdot 7$ & - & - & - & - & - \\
\hline $\begin{array}{l}\text { farms }(\mathrm{n}=43) \% \\
\text { Workers at chicken slaughterhouses }\end{array}$ & 0 & $14 \cdot 0$ & $14 \cdot 0$ & $23 \cdot 2$ & $7 \cdot 0$ & $18 \cdot 6$ & $16 \cdot 3$ & $4 \cdot 6$ & $2 \cdot 3$ & - & - & - \\
\hline $\begin{array}{l}\quad(n=17) \% \\
\text { Group exposed to quails: }\end{array}$ & 0 & $23 \cdot 6$ & $17 \cdot 6$ & $17 \cdot 6$ & $5 \cdot 9$ & $5 \cdot 9$ & $5 \cdot 9$ & $5 \cdot 9$ & $5 \cdot 9$ & $11 \cdot 7$ & - & - \\
\hline $\begin{array}{l}\text { Workers on quail farms including } \\
\text { quail slaughter }(n=40) \%\end{array}$ & 5.0 & $20 \cdot 0$ & $10 \cdot 0$ & 22.5 & 7.5 & $7 \cdot 5$ & 17.5 & 2.5 & 2.5 & 0 & 2.5 & 2.5 \\
\hline
\end{tabular}

Figure 1 Cumulative prevalence of antibodies against Marek's disease virus according to occupational exposure to chickens. Higher titres wer more frequent in exposed subjects than in unexposed subjects and in women than in men.

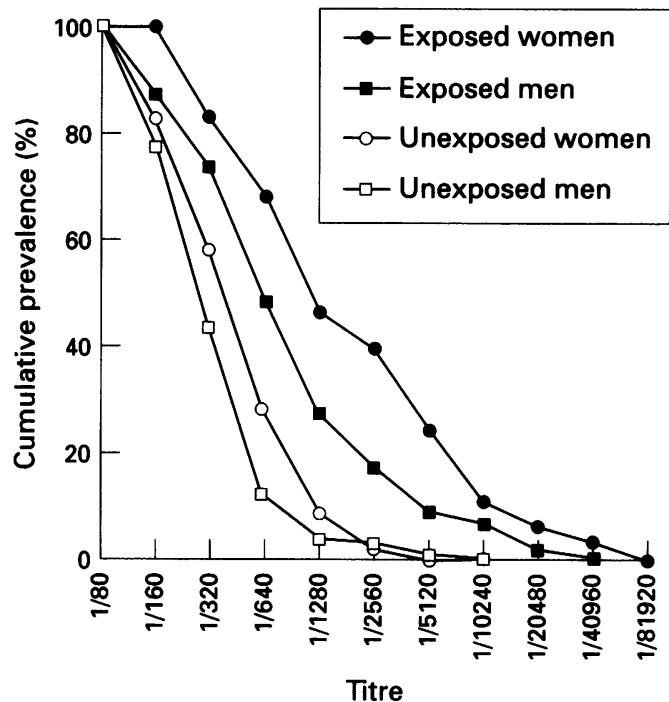

ing to sex and occupational groups (tables 2, 3, 7 and 8, and fig 1). Logarithmic transformation was used to normalise the distribution of optical densities. Thus, the arithmetic and geometric means for each dilution were calculated to compare the groups (figs 2-4). The prevalence of the titres against MDV higher than 1/640 was used to determine the odds ratios (ORs), to adjust for confounding factors, and to compare exposed and unexposed subjects. A P value lower than 0.05 was considered significant.

\section{Results}

Data concerning the demographic characteristics of the seven subgroups were collected by questionnaire (table 1). The difference in sex ratios between these subgroups showed the usual differences according to occupation. The percentage of women was high among workers on quail farms. The mean duration of exposure to animals was long, especially among traditional farmers with or without poultry. However, in these two subgroups the kinds of work were varied and the exposure to chickens was probably very different from one subject to another. The workers on quail farms were involved in breeding and also in slaughtering quails. The women in this subgroup seemed more exposed to animals than men. Such differences between men and women in the exposure to animals may also exist in the other subgroups and were considered in our results.

ANTIBODIES AGAINST MAREK'S DISEASE VIRUS In the overall population, antibodies were more often present at higher titres in the groups exposed to chickens than in unexposed groups (tables 2 and 3). No significant difference was found between the three subgroups not exposed to poultry (white collar workers, workers at cattle slaughterhouses, farmers in

Table 4 Multivariate analysis by logistic regression of titres against MDV higher than $1 / 640$ (the adjusted ORs of the occupational subgroups increased significantly with the exposure to chickens, among women, but not with age)

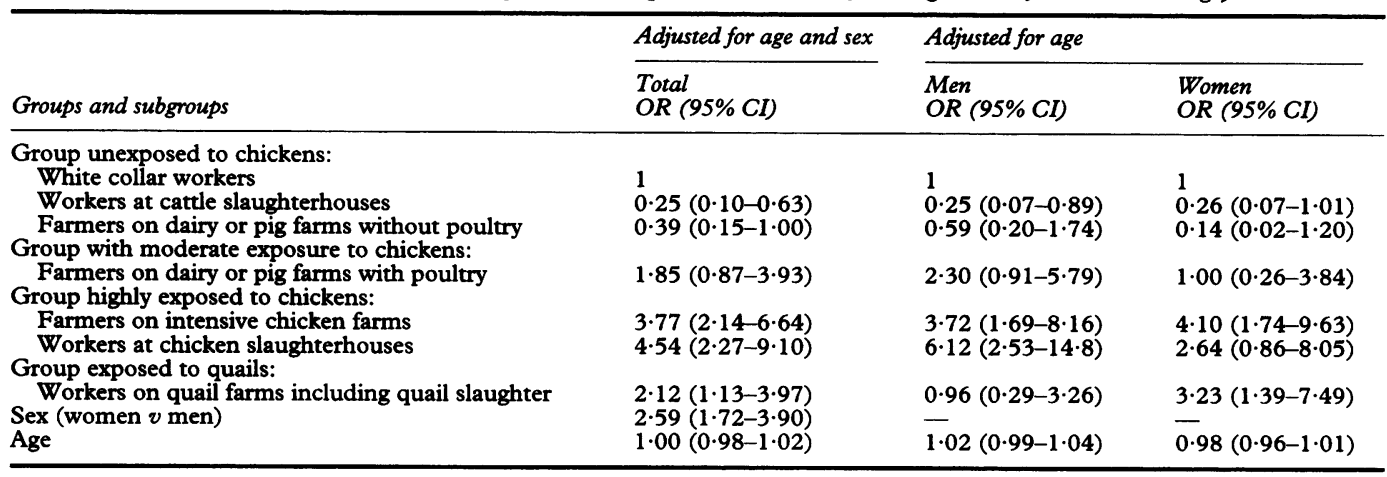


Table 5 Multivariate analysis by logistic regression of titres against MDV higher than $1 / 640$ in the groups unexposed to chickens, moderately exposed to chickens, and highly exposed to chickens

\begin{tabular}{|c|c|c|c|}
\hline \multirow[b]{2}{*}{ Groups } & \multirow{2}{*}{$\begin{array}{l}\begin{array}{l}\text { Adjusted for } \\
\text { age and sex }\end{array} \\
\text { Total } \\
\text { OR }(95 \% \text { CI) }\end{array}$} & \multicolumn{2}{|l|}{ Adjusted for age } \\
\hline & & $\begin{array}{l}\text { Men } \\
\text { OR }(95 \% C I)\end{array}$ & $\begin{array}{l}\text { Women } \\
\text { OR }(95 \% C I)\end{array}$ \\
\hline $\begin{array}{l}\text { Group unexposed to chickens } \\
\text { Group with moderate exposure to }\end{array}$ & 1 & 1 & 1 \\
\hline $\begin{array}{l}\text { chickens } \\
\text { Group highly exposed to chickens } \\
\text { Sex (women } v \text { men) }\end{array}$ & $\begin{array}{l}2 \cdot 71(1.32-5 \cdot 57) \\
6 \cdot 17(3.91-9 \cdot 75) \\
2 \cdot 28(1.48-3.53)\end{array}$ & $\begin{array}{l}3.40(1.43-8.06) \\
6.99(3.79-12.9)\end{array}$ & $\begin{array}{l}1 \cdot 51(0 \cdot 40-5 \cdot 71) \\
5 \cdot 48(2 \cdot 69-11 \cdot 1) \\
\end{array}$ \\
\hline Age & $1.00(0.99-1.02)$ & $1.02(0.99-1.05)$ & $0.98(0.95-1.01)$ \\
\hline
\end{tabular}

Table 6 Multivariate analysis by logistic regression of titres against MDV higher than $1 / 640$ in the groups unexposed to chickens, moderately exposed to chickens, and highly exposed to chickens (the adjusted ORs increased with the duration of exposure to chickens but not with age)

\begin{tabular}{|c|c|c|c|}
\hline \multirow[b]{2}{*}{ Groups } & \multirow{2}{*}{$\begin{array}{l}\text { Adjusted for } \\
\text { age and sex } \\
\text { Total } \\
\text { OR }(95 \% \text { CI })\end{array}$} & \multicolumn{2}{|l|}{ Adjusted for age } \\
\hline & & $\begin{array}{l}\text { Men } \\
\text { OR }(95 \% C I)\end{array}$ & $\begin{array}{l}\text { Women } \\
\text { OR }(95 \% \text { CI) }\end{array}$ \\
\hline $\begin{array}{l}\text { Duration of exposure: } \\
\text { Unexposed workers } \\
1-4 \text { years } \\
5-9 \text { years } \\
\geqslant 10 \text { years } \\
\text { Sex (women } v \text { men) }\end{array}$ & $\begin{array}{l}1 \\
4.50(2.36-8.59) \\
4.40(2 \cdot 23-8.67) \\
6.95(3.69-13 \cdot 1) \\
2.27(1.47-3.50)\end{array}$ & $\begin{array}{l}1 \\
5 \cdot 22(2 \cdot 09-13 \cdot 0) \\
3 \cdot 74(1 \cdot 53-9 \cdot 15) \\
7 \cdot 26(3 \cdot 40-15 \cdot 5) \\
-\quad\end{array}$ & $\begin{array}{l}1 \\
3 \cdot 69(1 \cdot 47-9 \cdot 28) \\
7 \cdot 68(2 \cdot 26-26 \cdot 1) \\
6 \cdot 47(2 \cdot 06-20 \cdot 3)\end{array}$ \\
\hline Age & $1.00(0.99-1.03)$ & $1.03(1.00-1.05)$ & $0.98(0.95-1.01)$ \\
\hline
\end{tabular}

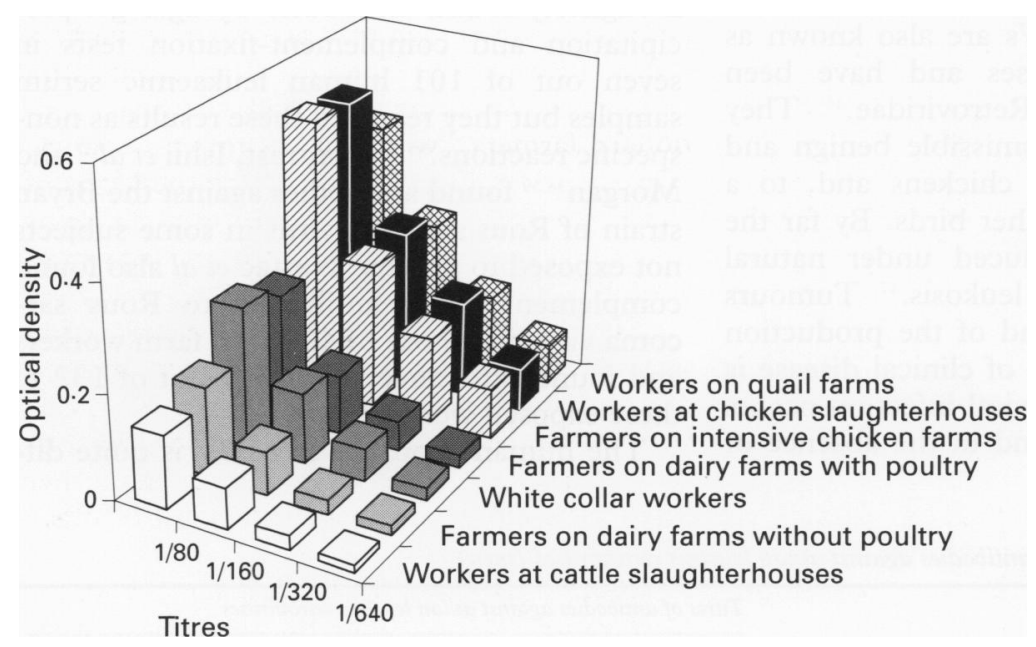

Figure 2 Geometric means of optical densities for antibodies against Marek's disease virus among women in each subgroup.

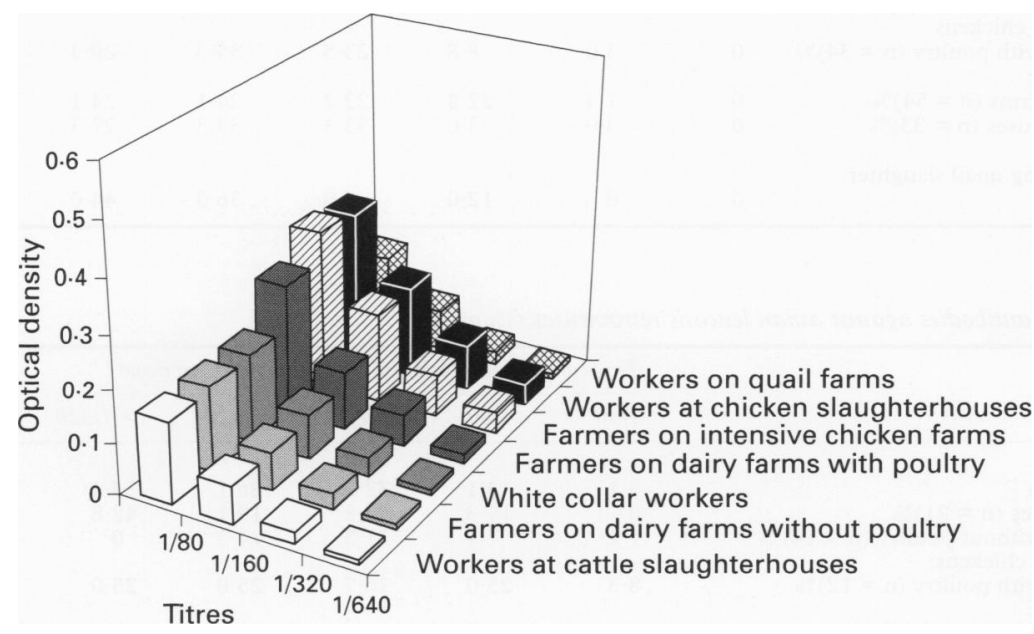

Figure 3 Geometric means of optical densities for antibodies against Marek's disease virus among men in each subgroup. dairy or pig farms without chickens). These three subgroups are pooled as unexposed subjects in fig 1 . No significant difference was found between the two subgroups with the higher exposure to chickens (farmers on intensive chicken farms and workers at chicken slaughterhouses). These two subgroups are pooled as exposed subjects in fig 1 . Significantly higher titres were more frequently found in workers exposed to chickens than in unexposed workers. The prevalence of titres in farmers on dairy or pig farms with poultry was intermediate. Their exposure to chickens was probably lower and heterogeneous in comparison with farmers who specialised in chickens and workers at chicken slaughterhouses (tables 2 and 3). The ORs were adjusted for age and sex by multivariate analysis. These ORs were significantly higher in subgroups exposed to chickens than in unexposed groups (tables 4 and 5). The ORs increased significantly in men and women according to the duration of exposure to chickens (table 6).

Similar results were found when comparing the values of optical densities. The geometric means of optical densities for each dilution were significantly higher in the two subgroups with higher exposure to chickens than in the three unexposed groups and intermediate values were found for the farmers with cattle and poultry (figs 2 and 3 ).

The prevalence of the titres in workers on quail farms was much higher among women than men with significant differences of geometric means (tables 2 and 3 and figs 2 and 3 ).

The decrease in values of optical densities after adsorption with chicken antigens was greater among exposed workers than among unexposed workers. Significant differences after adsorption remained only for crude MDV between exposed and unexposed women (fig 4). However, the concentration of antibodies in a few subjects, both men and women, remained very high and constant after adsorption.

\section{CROSS REACTION WITH HUMAN HERPES} VIRUSES

The prevalence of antibodies against cytomegalovirus was similar among subjects with and without antibodies against MDV (29.5\% and $31.8 \%$ respectively). No cross reaction was found.

All subjects except one had antibodies against Herpes varicellae. Thus, no cross reaction was found. However, the prevalence of antibodies against Herpes simplex was slightly higher among subjects with antibodies against MDV than among subjects without such antibodies ( $91 \% v 75 \%$ respectively, $P=0.05)$.

\section{ANTIBODIES AGAINST AVIAN LEUKOSIS} RETROVIRUSES

No significant difference was found between subgroups for the prevalence of titres of antibodies against ALV nor for the mean values of optical density (tables 7 and 8). However, significant differences between men and women were found. 


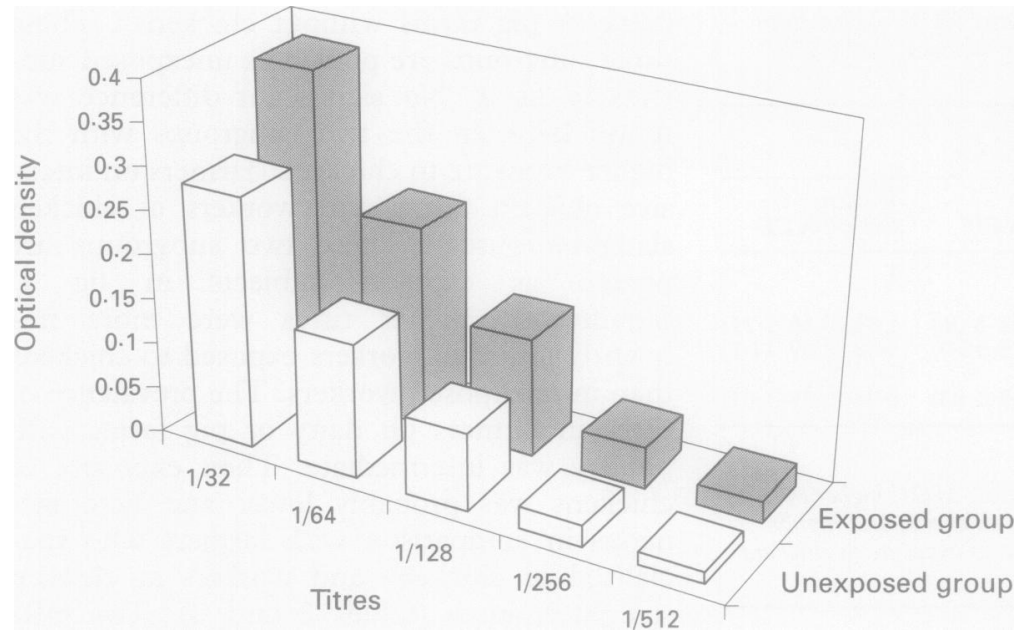

Figure 4 Geometric means of optical densities for antibodies after adsorption with crude Marek's disease virus among highly exposed and unexposed women.

\section{Discussion}

Cancers induced by viruses were shown first in animal experimental studies and confirmed by epidemiological surveys. Some viruses such as MDV are highly contagious. Until recently, few investigations have been performed to determine the potential role of animal oncogenic viruses such as $A L V$ and $M D V$ in human cancer. The ALVs are also known as avian type $\mathrm{C}$ oncoviruses and have been placed in the family Retroviridae. ${ }^{46}$ They induce a variety of transmissible benign and malignant neoplasms in chickens and, to a much lesser extent, in other birds. By far the most common type induced under natural conditions is lymphoid leukosis. ${ }^{47}$ Tumours mainly develop at the end of the production period and the incidence of clinical disease is generally low. However, viral infection occurs in most chicken flocks and in the absence of overt disease it affects productivity of chickens. ${ }^{48}$ Chickens are the natural hosts for ALVs that are transmitted mainly vertically from hen to progeny through the egg, and horizontally from bird to bird by close contact. ${ }^{49}$ Workers may be infected by scratch injury during breeding operations, manual sexing, or artificial insemination. The means of transmission and the greater liability of ALV compared with MDV could explain the lower risk of transmission of ALV to humans. These facts are in agreement with our results for ALV because no difference was detected for the prevalence of antibodies between exposed and unexposed workers.

Most of the studies that have sought antibodies against ALV have been negative or their results were considered to be non-specific. ${ }^{25}$ Solomon et al did not find ALVs or antiviral activity by blood neutralisation of leukaemic and non-leukaemic subjects. ${ }^{34}$ Piraino et al did not find neutralising antibodies to the Bryan standard strain of Rous sarcoma virus among 111 subjects who had received a vaccine against yellow fever virus contaminated with ALVs. ${ }^{35}$ Also, Waters et al did not find an increased risk of cancer among the subjects contaminated by ALV. ${ }^{50}$ Roth and Dougherty found antibodies by agar-gel precipitation and complement-fixation tests in seven out of 101 human leukaemic serum samples but they reported these results as nonspecific reactions. ${ }^{36}$ In contrast, Ishii et al $^{37}$ and Morgan $^{38}{ }^{39}$ found antibodies against the Bryan strain of Rous sarcoma virus in some subjects not exposed to poultry. Nastac et al also found complement fixing antibodies to Rous sarcoma virus in $\mathbf{9 0}$ out of $\mathbf{4 0 2}$ fowl farm workers and found seroconversion in 19 out of 132 of these exposed workers. ${ }^{30}$

The human exposure to MDV is quite dif-

Table 7 Prevalence of titres of antibodies against avian leucosis retroviruses (men)

\begin{tabular}{|c|c|c|c|c|c|c|}
\hline \multirow[b]{2}{*}{ Groups } & \multicolumn{6}{|c|}{ Titres of antibodies against avian leucosis retroviruses } \\
\hline & $1 / 20$ & $1 / 40$ & $1 / 80$ & $1 / 160$ & $1 / 320$ & $>1 / 320$ \\
\hline \multicolumn{7}{|l|}{ Group unexposed to chickens: } \\
\hline White collar workers $(n=91) \%$ & 0 & $5 \cdot 5$ & $17 \cdot 6$ & $29 \cdot 7$ & $22 \cdot 0$ & $25 \cdot 2$ \\
\hline Workers at cattle slaughterhouses $(n=66) \%$ & $1 \cdot 5$ & $6 \cdot 1$ & $9 \cdot 1$ & $19 \cdot 7$ & $25 \cdot 7$ & 37.9 \\
\hline Farmers on dairy or pig farms without poultry & 0 & $7 \cdot 1$ & 14.3 & $26 \cdot 2$ & 40.5 & 11.0 \\
\hline Group with moderate exposure to chickens: & & & & & & \\
\hline Farmers on dairy or pig farms with poultry $(n=34) \%$ & 0 & $3 \cdot 0$ & $8 \cdot 8$ & $23 \cdot 5$ & $35 \cdot 3$ & $29 \cdot 4$ \\
\hline Group highly exposed to chickens: & & & & & & \\
\hline Farmers on intensive chicken farms $(n=54) \%$ & 0 & $7 \cdot 4$ & $22 \cdot 2$ & $22 \cdot 2$ & $24 \cdot 1$ & $24 \cdot 1$ \\
\hline Workers at chicken slaughterhouses $(n=33) \%$ & 0 & $3 \cdot 0$ & $3 \cdot 0$ & $33 \cdot 3$ & $33 \cdot 3$ & $27 \cdot 3$ \\
\hline \multicolumn{7}{|l|}{ Group exposed to quails: } \\
\hline $\begin{array}{l}\text { Workers on quail farms including quail slaughter } \\
(\mathrm{n}=25) \%\end{array}$ & 0 & 0 & $12 \cdot 0$ & $8 \cdot 0$ & $36 \cdot 0$ & $44 \cdot 0$ \\
\hline
\end{tabular}

Table 8 Prevalence of titres of antibodies against avian leucosis retroviruses (women)

\begin{tabular}{|c|c|c|c|c|c|}
\hline \multirow[b]{2}{*}{ Groups } & \multicolumn{5}{|c|}{ Titres of antibodies against avian leucosis retroviruses } \\
\hline & $1 / 40$ & $1 / 80$ & $1 / 160$ & $1 / 320$ & $>1 / 320$ \\
\hline \multicolumn{6}{|l|}{ Group unexposed to chickens: } \\
\hline White collar workers $(n=65) \%$ & $3 \cdot 1$ & $3 \cdot 1$ & $32 \cdot 3$ & $26 \cdot 1$ & $35 \cdot 4$ \\
\hline Workers at cattle slaughterhouses $(n=21) \%$ & 0 & $14 \cdot 3$ & 23.8 & $19 \cdot 1$ & $42 \cdot 8$ \\
\hline Farmers on dairy or pig farms without poultry $(n=14) \%$ & $7 \cdot 1$ & $7 \cdot 1$ & 71.5 & $14 \cdot 3$ & 0 \\
\hline \multicolumn{6}{|l|}{ Group with moderate exposure to chickens: } \\
\hline Farmers on dairy or pig farms with poultry $(n=12) \%$ & $8 \cdot 3$ & $25 \cdot 0$ & $16 \cdot 7$ & $25 \cdot 0$ & $25 \cdot 0$ \\
\hline \multicolumn{6}{|l|}{ Group highly exposed to chickens: } \\
\hline Farmers on intensive chicken farms $(n=44) \%$ & $4 \cdot 5$ & $11 \cdot 4$ & $34 \cdot 1$ & $11 \cdot 4$ & $38 \cdot 6$ \\
\hline Workers at chicken slaughterhouses $(n=18) \%$ & 0 & $5 \cdot 5$ & $16 \cdot 7$ & $27 \cdot 8$ & $50 \cdot 0$ \\
\hline \multicolumn{6}{|l|}{ Group exposed to quails: } \\
\hline Workers on quail farms including quail slaughter $(n=42) \%$ & 0 & 0 & $14 \cdot 3$ & $19 \cdot 0$ & $66 \cdot 7$ \\
\hline
\end{tabular}


ferent from ALV. The MDV induces a lymphoproliferative disease of chickens characterised by malignant transformation of CD4 helper $\mathrm{T}$ lymphocytes. This virus, together with Epstein-Barr virus, has been classified as a gamma herpes virus on the basis of its biological properties.

However, the genome structure of MDV indicates a closer relation to alpha herpes viruses such as Herpes simplex that is very common in humans. ${ }^{51-53}$ The MDV is quite widespread in chicken populations and is efficiently transmitted through the air in poultry house dust and chicken dander. ${ }^{54}$ The chickens in the flocks were vaccinated against MDV during the period of the study, by the Herpes virus of turkey (HVT). This vaccine strain of virus, which is also present in the flocks, is not excreted at the feather follicle level and thus is not airborne as is MDV. The vaccinal virus could therefore not be inhaled by the workers. This vaccination is effective against expression of disease but not against contamination and multiplication of wild viruses. Consequently, MDV is widespread in all flocks, and in breeding houses and slaughterhouses the workers are continuously exposed and inhale avian oncogenic viruses. This exposure may explain the occurrence of antibodies against $\mathrm{MDV}$ in the exposed groups studied (fig 1). These findings confirm the detection by Naito et al of antibodies against MDV in fowl farm workers who had direct contact with diseased fowl. ${ }^{31}{ }^{32}$ Sharma et al also found antibodies against MDV in humans but without apparent correlation with occupational exposure to chickens. ${ }^{33}$ The prevalence of antibodies was $0 \%$ among 23 full time employees at a chicken dressing plant, $4 \%$ among 24 broiler raisers, $18 \%$ among 17 employees at a laboratory involved in MDV research, and 8\% among 50 control subjects. The control workers in our study might have been slightly exposed to avian viruses during childhood or might have been in contact with wild birds, thus explaining some low titres.

Furthermore, numerous epidemiological studies have shown an increased risk of tumours of the haematopoietic and lymphatic systems among agricultural workers ${ }^{1-3}$ and also among veterinarians, slaughterhouse workers, and meat inspectors with limited exposure to pesticides. ${ }^{20-24}$ Bovine leukaemia virus and avian oncogenic viruses have therefore been suspected of being associated with these human cancers.

However, exposure to poultry was not precisely assessed in most studies, ${ }^{26811}$ confounding exposures were difficult to separate, ${ }^{625}$ and the sample sizes of some populations studied were not large enough to find a significantly increased risk. 1314222325

In spite of these difficulties, several studies have indicated an association between exposure to poultry and cancers of the haematopoietic and lymphatic systems. ${ }^{10} 15-1923$

Moreover, sex differences in occupational exposure to animals and in the occurrence of cancer were not always mentioned. Women are often involved in breeding poultry.
Interestingly, among farmers, the risk of multiple myeloma in the United States ${ }^{5}$ and multiple myeloma and leukaemia in Denmark and Italy $^{2}$ were significantly higher among women. We also found a higher prevalence of antibodies against avian oncogenic viruses among women. It has also been shown that female chickens are more sensitive than males to $M D V^{55}$ and $A L V .{ }^{56}$ Thus, the difference found between men and women in our study may be induced by genetic factors, as in chickens, or by differences in exposure.

In our study occupational contacts with poultry were associated with a higher percentage of workers with high antibody concentrations against $\mathrm{MDV}$. The significance of these antibodies in humans is still unclear. Titres decreased after adsorption with chicken antigens and the differences between exposed and unexposed groups were less significant. However, some subjects still had high titres of specific antibodies. Antigenic relations have already been reported between herpes viruses from different species. $^{57} \mathrm{We}$ determined whether there was a cross reaction against human herpes viruses and no relation was found, except for Herpes simplex. This finding may be explained by one major viral glycoprotein which is homologous in MDV and Herpes simplex. ${ }^{58}$ The meaning of these high titres could be related to the presence of $\mathrm{MDV}$ in humans. As the organisation of the MDV genome is known, ${ }^{589}$ and DNA-specific probes for MDV will be available, and as MDV is integrated into the host cell genome in chickens, we plan to investigate the integration of viral DNA into cells of exposed workers and of subjects with cancer.

We thank the occupational physicians of the Mutualite Sociale Agricole for their help in collecting the data: $G$ Aussedat, $H$ Agricole for their help in collecting the data: G Aussedat, $\mathbf{H}$ Blanchet, J Bordet, M Bouche, J L Deutscher, M F Doudet. The serological tests with avian viruses were performed by $N$ reactions with herpes and CMV were performed by Professor A Goudeau and $\mathrm{Dr} \mathrm{C}$ Lesage. The statistical analyses were reviewed by $\mathrm{Y}$ Iwatsubo. This study was supported by the Ministère de la Recherche et de la Technologie (Département Homme, Travail et Technologies), by the Mutualité Sociale Agricole, and by the Association pour la Prévention des Maladies Professionnelles et des Accidents du travail.

1 Blair A, Zahm SH, Pearce NE, Heineman EF, Fraumeni JF. Clues to cancer etiology from studies of farmers. Scand $\mathcal{F}$ Work Environ Health 1992;18:209-15.

2 Ronco G, Costa G, Lynge E. Cancer risk among Danish and Italian farmers. Br $\mathcal{F}$ Ind Med 1992;49:220-5.

3 Pearce N, Reif JS. Epidemiologic studies of cancer in agricultural workers. Am F Ind Med 1990;18:133-48.

4 Fasal A, Jackson EW, Klauber MR. Leukemia and lymphoma mortality and farm residence. Am $\mathcal{f}$ Epidemiol 1968;87:267-74.

5 Zahm SH, Blair A, Weisenburger DD. Sex differences in the risk of multiple myeloma associated with agriculture. Br F Ind Med 1992;49:815-6.

6 Pearce NE, Sheppard RA, Howard JK, Fraser J, Lilley BM. Leukemia among New Zealand agricultural workers. A cancer registry-based study. Am $尹$ Epidemiol 1986;124: 402-9.

7 Zahm SH, Blair A, Holmes FF, Boysen CD, Robel RJ. A case-referent study of soft-tissue sarcoma and Hodgkin's disease. Farming and insecticide use. Scand $\mathcal{f}$ Work Environ Health 1988;14:224-30.

8 Dubrow R, Paulson JO, Indian RW. Farming and malignant lymphoma in Handcock county, Ohio. Br f Ind Med 1988;45:25-8.

9 Persson B, Dahlander AM, Fredriksson M, Brage HN, Ohlson CG, Axelson O. Malignant lymphomas and occupational exposures. Br f Ind Med 1989;46:516-20.

10 Milham S. Leukemia and multiple myeloma in farmers. $\mathrm{Am}$ f Epidemiol 1971;94:307-10.

11 Priester WA, Mason TJ. Human cancer mortality in relation to poultry population, by county, in 10 southeastern states. $\mathscr{f}$ Nat Cancer Inst 1974;53:45-9. 
12 Eriksson $M$, Karlsson $M$. Occupational and other environmental factors and multiple myeloma. a population based case-control study. Br F Ind Med 1992;49:95-103.

13 Saftlas AF, Blair A, Cantor KP, Hanrahan L, Anderson HA. Cancer and other causes of death among Wisconsin farmers. Am f Ind Med 1987;11:119-29.

14 Cantor KP. Farming and mortality from non-Hodgkin's lymphoma: a case-control study. Int $\mathcal{F}$ Cancer 1982;29: $239-47$.

15 Blair A, Thomas TL. Leukemia among Nebraska farmers: a death certificate study. Am f Epidemiol 1979;110:264-73.

16 Burmeister LF, Van Lier SF, Isacson P. Leukemia and farm practices in Iowa. Am $\mathcal{F}$ Epidemiol 1982;115:720-8.

17 Bross IDJ, Bertell R, Gibson R. Pets and adult leukemia. $A m$ f Public Health 1972;62:1520-31.

18 Burmeister LF, Everett GD, Van Lier SF, Isacson P. Selected cancer mortality and farm practices in Iowa. $A m \mathcal{F}$ Epidemiol 1983;118:72-7.

19 Cantor KP, Blair A. Farming and mortality from multiple myeloma: a case-control study with the use of death cermyeloma: a case-control study with the

20 Johnson ES, Fischman HR. Cancer mortality among butchers and slaughterhouse workers. Lancet 1982;i:913-4.

21 Johnson ES, Fischman HR, Matanoski GM, Diamond E. Cancer mortality among white males in the meat industry. f Occup Med 1986;28:23-32.

22 Johnson ES, Fischman HR, Matanoski GM, Diamond E. Occurence of cancer in women in the meat industry. $\mathrm{Br} \mathcal{F}$ Ind Med 1986;43:597-604.

23 Johnson ES. Mortality among non-white men in the meat industry. 7 Occup Med 1989;31:270-2.

24 Gubéran E, Usel M, Raymond L, Fioretta G. Mortality and incidence of cancer among a cohort of self employed butchers from Ge

25 Johnson ES. Poultry oncogenic retroviruses and humans. Cancer Detect Prev 1994;18:9-30.

26 Purchase H, Payne LN. Neoplasic diseases: leukosis-sarcoma group. In: MS Hofstad, et al, eds. Disease of poultry. Ames: Iowa State University Press, 360-405.

27 Calnek BW. Marek's disease: a model for herpes virus oncology. Crit Rev Microbiol 1986;12:293-320.

28 Calothy G, Poirier F, Dambrine G, Pessac B. A transformation defective mutant of Rous sarcoma virus inducing chick embryo neuroretinal cell proliferation. Virology 1978;89:75-84.

29 Nastac E, Stoian M, Predescu E, Chira M, Hozoc M, Athanasiu $\mathrm{P}$, et al. The presence of complement fixing
antibodies to the avian group specific ("gs") sarcomaantibodies to the avian group specific ("gs") sarcoma-
leukosis antigen in the human population and in cancer leukosis antigen in the human population and in cancer patients.

30 Nastac E, Predescu E, Stoian M, Chira M, Hozoc M, Suru $M$, Ibric $L$. Investigations on the incidence of complement fixing antibodies to the avian group-specific ("gs") sar-
coma-leukosis antigen in fowl farm workers. Revue Roumaine de Medecine-Virologie 1978;29:41-5.

31 Naito $M$, Ono $K$, Tanabe S, Doi T, Kato S. Detection in chicken and human sera of antibody against herpes type virus from a chicken with Marek's disease and EB virus virus from a chicken with Marek's disease and EB virus demonstrated by the indirect
Biken fournal 1970;13:205-12.

32 Naito M, Ono K, Doi T, Kato S, Tanabe S. Antibodies in human and monkey sera to herpes-type virus from a chicken with Marek's disease and to EB virus detected by the immunofluorescence test. Biken fournal 1971;14:161-6.

33 Sharma JM, Witter RL, Burmester BR, Landon JC. Public health implications of Marek's disease virus and herpesvirus of turkeys. Studies on human and subhuman primates. $\mathcal{F}$ Nat Cancer Inst 1973;51:1123-8.

34 Solomon JJ, Purchase HG, Burmester BR. A search for avian leukosis virus and anti-viral activity in the blood of leukemic and non-leukemic adults and children. $f \mathrm{Nat}$ Cancer Inst 1969;42:29-33.

35 Piraino F, Krumbiegel ER, Wisniewski HJ. Serologic survey of man for avian leukosis virus infection. $\mathcal{F}$ Immunol 1967;98:702-6.

36 Roth FK, Dougherty RM. Search for group-specific antibod- ies of avian leukosis virus in human leukemic sera. $\mathcal{f} \mathrm{Nat}$ Cancer Inst 1971;46:1357-60.

37 Ishii K, Koyama K, Shimojo H, Kawamura A, Aoyama Y, Nishioka $\mathrm{K}$. Antibody to oncogenic viruses in sera of cancer patients. GANN Monogr 1969;7:157-62.

38 Morgan HR. Antibodies for Rous sarcoma virus (Bryan) in fowl, animal, and human populations of East Africa. II Antibodies in domestic chickens, wildfowl, primates, and Antibodies in domestic chickens, wildfowl, primates, and
man in Kenya, and antibodies for Burkitt lymphoma cells in man. $\mathcal{F}$ Natl Cancer Inst 1967;39:1229-34.

39 Morgan HR. Avian leukosis sarcoma virus antibodies in wildfowl, domestic chickens and man in Kenya. Proc Soc Exp Biol Med 1973;144:1-4.

40 Cohen S, Weiner LM, Baechler CA, Stulberg CS. Immunologic cross-reaction between human leukemic plasma and avian leukosis oroup-specific antiserum (35147). Proc Soc Exp Biol Med 1970;135:800-3.

41 Smith EJ. Preparation of antisera to group-specific antigens of avian leukosis-sarcoma viruses: an alternate approach. Avian Dis 1977;21:290-9.

42 Smith PK, Krohn RI, Hermanson GT, et al. Measurement of protein using bicinchoninic acid. Anal Biochem 1985; 150:76-85.

43 Graf B, Coudert F, Dambrine G, Mazzella O, Cauchy L. Differenciation of an epiperiosteal sheath in avian hyperostosis induced by myeloblastosis associated virus MAV-2 (0). Ann Rech Vet 1988;19:45-52.

44 Purchase HG, Biggs PM. Characterization of five isolates of Marek's disease. Res Vet Sci 1967;8:440-9.

45 Coudert F, Ahluwalia R. Antigen requirements and specificity of a microplate enzyme linked immunosorbent assay (ELISA) for Marek's disease viral antibodies in chicken. Ann Rech Vet 1984;15:529-34.

46 Mathews REF. Fourth report of the International Committee on Taxonomy of Viruses. Classification and nomenclature of viruses. Intervirology 1982;17:1-3.

47 Payne LN, Purchase HG. Neoplastic diseases: leukosis/ sarcoma group. In: Calnek, ed. Diseases of poultry. Ames, Iowa: Wolfe, 1991:386-439.

48 Gavora JS, Spencer JL, Gowe RS, Harris DL. Lymphoid leukosis virus infection: effects on production and mortality and consequences in selection for high egg production. Poult Sci 1980;59:2165-78.

49 Rubin H, Cornelius A, Fanshier L. The pattern of congenital transmission of an avian leukosis virus. Proc Natl Acad Sci USA 1961;47:1058-60.

50 Waters TD, Anderson PS, Beebe GW, Miller RW. Yellow fever vacination, avian leukosis virus, and cancer risk in man Science 1972:177:76-7.

51 Cebrian J, Dierich CK, Berthelot N, Sheldrick P. Inverted repeat nucleotide sequences in the genomes of Marek's disease virus and the herpesvirus of the turkey. Proc Nat Acad Sci USA 1982;79:555-8.

52 Buckmaster AE, Scott SD, Sanderson MJ, Boursnell MEG, Ross NLJ, Binns MM. Gene sequence and mappping data from Marek's disease virus and herpesvirus of turkeys: implications for herpesvirus classification. f Gen Virol 1988;69:2033-42.

53 Velicer LF, Brunovskis P. Genomic organization of herpesviruses in Marek's disease system. Proceedings of the XIX World Poultry Congress 1992;1:33-9.

54 Beasley JN, Patterson LT, McWade DH. Transmission of Marek disease by poultry house dust and chicken dander. Am F Vet Res 1970;31:339-44.

55 Payne LN, Frazier JA, Powell PC. Pathogenesis of Marek's disease. Int Rev Exp Pathol 1976;16:59-145.

56 De Boer GF. Avian leukosis. Boston: Martinus Nijhoff, 1987.

57 Evans DL, Barnett JW, Bowen JM, Dmochowski L Antigenic relationship between the herpes viruses of infectious bovine rhinotracheitis, Marek's disease, and Burkitt's lym phoma. ₹ Virol 1972;10:277-87.

58 Ross N, Milne B, Biggs P. Restriction endonuclease analysis of MDV DNA and homology between strains. 7 Gen Virol 1983;64:2785-90.

59 Fukuchi K, Tanaka A, Schierman LW, Witter RL, Nonoyama $\mathrm{X}$. The structure of Marek's disease virus DNA: the presence of unique expansion in non pathogenic viral DNA. Proc Natl Acad Sci 1985;82:751-4. 